\title{
PENGGUNAAN MODEL PEMBELAJARAN PROBLEM BASE LEARNING UNTUK MENINGKATKAN PEMAHAMAN SISWA KELAS XI TATA BUSANA-2 MATA PELAJARAN PEMBUATAN BUSANA INDUSTRI MATERI PENGERTIAN DAN FUNGSI BUSANA PESTA PADA SMK NEGERI 1 SIGLI
}

\author{
Fitri Yanti
}

\begin{abstract}
ABSTRAK
Penggunaan Model Pembelajaran Problem Base Learning Untuk Meningkatkan Pemahaman Siswa Kelas XI Tata Busana-2 Mata Pelajaran Pembuatan Busana Industri Materi Pengertian dan Fungsi Busana Pesta Pada SMK Negeri 1 Sigli. Penelitian ini dilakukan di SMK Negeri 1 Sigli selama tiga bulan sejak bulan JanuarisampaidenganMaret 2020 bertujuan untuk meningkatkan pemahaman melalui penggunaan model pembelajaran problem base learning pada materi pengertian dan fungsi busana pesta bagi siswa kelas XI Tata Busana-2 SMK Negeri 1 Sigli. Metode penelitian yang digunakan adalah penelitian tindakan kelas (PTK) yang terdiri atas 2 siklus. Subyek penelitian adalah siswa-siswi Kelas XI Tata Busana-2 SMK Negeri 1 Sigli tahun pelajaran 2019/2020 sebanyak 30 siswa. Analisis data menggunakan teknik analisis deskriptif komparatif dengan membandingkan kondisi awal dengan hasil-hasil yang dicapai pada setiap siklus, dan analisis deskriptif kualitatif hasil observasi dengan membandingkan hasil observasi dan refleksi pada siklus I dan siklus 2.Hasil penelitian diperolehantaralain hasil tes pada siklus I dengan persentase ketuntasan sebesar 70\% nilai rata-rata kelas sebesar 75,8 dan meningkat pada hasil tes siklus II sebesar 93,3\% dengan nilai rata-rata kelas 85,2. Pada kedua siklus ini terjadi perubahan aktifitas dan perolehan nilai yang signifikan bila dibandingkan dengan pra siklus dengan ketuntasan belajar yang hanya mencapai $46,7 \%$ dan nilai rata-rata adalah 53,3. Dapat disimpulkan bahwamelalui penggunaan model pembelajaran problem base learning dapat meningkatkan pemahaman siswa pada materiakuntansi sebagai sistem informasi bagi siswa kelas XI Tata Busana-2 SMK Negeri 1 Sigli. Selain itu, hasil pengamatan pada proses belajar mengajar memperlihatkan perubahan siswa lebih aktif pada siklus I dan siklus II.
\end{abstract}

Kata Kunci : Model PembelajaranProblem Base LearningPengertian dan Fungsi busana Pesta

\section{PENDAHULUAN}

Pembelajaran merupakan bagian dariPendidikan, yang di dalamnya ditunjang oleh berbagai unsur pembelajaranantara lain tujuan, materi pelajaran, sarana prasarana, situasi atau kondisi belajar,media pembelajaran, lingkungan belajar, metode pembelajaran, serta evaluasi.Kesemua unsur pembelajaran tersebut sangat mempengaruhi keberhasilanproses belajar mengajar untuk meningkatkan prestasi belajar siswa.

Permasalahan yang timbul dalam pendidikan selama ini masih didominasi olehpandangan bahwa pengetahuan sebagai perangkat fakta-fakta yang harus dihafal.Termasuk mata pelajaran pembuatan busana industri. Disisi lain adanya banyak fakta bahwa gurumenguasai materi suatu subjek dengan baik tetapi tidak dapat melaksanakankegiatan pembelajaran dengan baik.Proses belajar mengajar di dalam kelas masih berfokus pada guru sebagai sumber utama pengetahuan, dimana ceramah menjadi pilihan utama proses belajar mengajar.

Melihat kondisi awal di kelas XI Tata Busana-2 Mata Pelajaran Pembuatan Busana Industri di SMK Negeri 1 Sigli ketuntasan 
belajar yang hanya mencapai $46,7 \%$ dan nilai rata-rata adalah 66,2. Maka penulis memutuskan untuk merubah model pembelajaran menjadi model pembelajaran problem base learning (PBL).Diharapkan model PBL lebih efektif bila dibandingkan dengan metode konvensional. Keefektifan model ini adalah siswa lebih aktif dalam berfikir dan memahami materi secara berkelompok dengan melakukan investigasi dan inquiri terhadap permasalahan yang real di sekitarnya sehingga mereka mendapatkan kesan yang mendalam dan lebih bermakna tentang apa yang mereka pelajari. Melalui penerapan model pembelajaran problem base learning diharapkan dapat meningkatkan Pemahaman Siswa Kelas XI Tata Busana2Mata Pelajaran Pembuatan Busana Industri Materi Pengertian dan Fungsi Busana Pesta Pada SMK Negeri 1 Sigli”.

\section{TINJAUAN PUSTAKA}

Hamalik (2008) mengemukakan bahwa "Belajar adalah suatu proses perubahan tingkah laku individu melalui interaksi dengan lingkungan".Perubahan tingkah laku yang dapat diamati dari penampilan orang yang belajar adalah hasil belajar.

Menurut Sutrisno (2006) menyatakan bahwa hasil belajar merupakan sesuatu yang diperoleh dari dan sesudah kegiatan pembelajaran berlangsung. Hasil belajar ini dinyatakan dalam bentuk angka, huruf atau kata-kata baik, sedang dan kurang. Hasil belajar ini merupakan kemampuan aktual yang dapat diukur langsung melalui tes yang sesuai dengan tujuan pembelajaran.Siswa yang menjalani proses belajar, supaya berhasil dengan tujuan yang ingin dicapai perlu memperhatikan beberapa faktor yang dapat mempengaruhi hasil belajarnya, secara umum faktor tersebut terbagi dalam dua kategori, menurut Slameto (2003) adalah: "Faktor-faktor yang mempengaruhi hasil belajar banyak jenisnya, tetapi dapat digolongkan menjadi dua golongan saja, yaitu faktor intern dan faktor ekstern. Faktor intern adalah faktor yang ada dalam diri individu yang sedang belajar, sedangkan faktor ekstern adalah faktor yang ada di luar individu." salah satu faktor ekstern yang dapat memberti dampak langsung terhadap hasil belajar siswa kondisi belajar dan model pembelajaran yang digunakan oleh guru.

Menurut Sudjana (2009:85), "praktek model pembelajaran pemecahan masalah berdasarkan tujuan dan bahan pengajaran, guru menjelaskan apa yang harus dicapai siswa dan kegiatan belajar yang harus dilaksanakannya (langkah-langkahnya. Sedangkan menurut Anies (2003), "Model problem-based learning adalah suatu metode instruksional yang mempunyai ciri-ciri penggunaan masalah nyata sebagai konteks siswa yang mempelajari cara berpikir kritis serta keterampilan dalam memecahkan masalah"

Penerapan model Problem Based Learning memiliki beberapa kekuatan, antara lain :
a. Fokus kebermaknaan, bukan fakta (deep versus surface learning)
b. Meningkatkan kemampuan siswa untuk berinisiatif
c. Pengembanganketerampilan dan pengetahuan
d. Pengembangan keterampilan interpersonal dan dinamika kelompok
e. Pengembangan sikap self-motivated
f. Tumbuhnya hubungan siswa-fasilitator
g. Jenjang penyampaian pembelajaran dapat ditingkatkan. (Taufiq Amir, 2009:27),

\section{METODOLOGI PENELITIAN}

Penelitian dilaksanakan di SMK Negeri 1 Sigli di kelas XI Tata Busana-2 pada materi pengertian dan fungsi busana pesta. Penelitian dilaksanakan selama 3 bulan yaitu pada bulan Januari s/d Maret 2020. Subyek penelitian adalah siswa-siswi Kelas XI Tata Busana-2 tahun pelajaran 2019/2020 dengan jumlah siswa sebanyak 30 orang. Data yang diperoleh berasal dari siswa kelas XI Tata Busana-2dan guru/teman sejawat yang 
merupakan guru kolaborasi dalam melaksanakan kegiatan penelitian di SMK Negeri 1 Sigli.

Teknik pengumpulan data yang dilakukan dengan observasi dan tes. Alat pengumpulan data yang digunakan adalah: Lembar instrument aktifitas siswa dalam PBM, Lembar intrumen PBM guru dan butir soal test. Analisis data yang digunakan adalah analisis deskriptif.

Dalam penelitian ini menggunakan dan mengembangkan siklus yang mengandung empat komponen yaitu: rencana Tindakan (planning), (2) pelaksanaan (action), (3) observasi (observation), (4) refleksi (reflection).

\section{HASIL PEMBAHASAN}

Pada kondisi pra siklus dengan ketuntasan belajar yang hanya mencapai $46,7 \%$ dan nilai rata-rata adalah $66,2$. Pada siklus I terjadi dua kali pertemuan atau dua kali tatap muka. Berdasarkan hasil pengamatan, keberhasilan yang telah dicapai pada siklus I adalah sebagai berikut:

Pada Siklus I aktifitassiswa pada pertemuan 1 dan pertemuan 2 masih sangat kurang, dimana persentase rata-rata aktivitas siswa adalah 30,90 \% pada pertemuan pertama dan $38,18 \%$ pada pertemuan kedua. Secara keseluruhan aspek-aspek pengamatan, skor tertinggi yang diperoleh pada siklus I adalah 3 dan terendah 1 . Sehingga nilai hasil akhir belajar pada siklus I diperoleh ketuntasan adalah21 siswa (70\%) dari 30 siswa keseluruhannya dinyatakan tuntas dan 9 siswa (30\%) dinyatakan tidak tuntas, dengan perolehan nilai rata-rata kelas sebesar 75,8 .

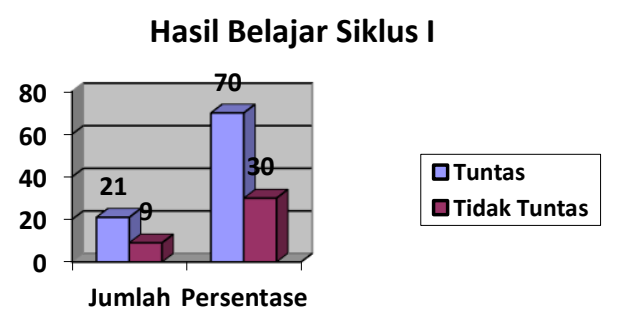

Pada siklus II aktivitas siswa meningkat bila dibandingkan dengan siklus I. Persentase aktivitas siswa sebesar $81,8 \%$ dengan skor tertinggi adalah 5 yang diperoleh siswa untuk beberapa aspek pengamatan dan terendah 3 . Persentase aktivitas siswa pada pertemuan ketiga siklus II sebesar 50,8\% siswa yang aktif.Sedangkanuntuknilaihasilakhirbelajardi peroleh ketuntasan 28 siswa $(93,3 \%)$ dari 30 siswa keseluruhannya dan 2 siswa $(6,7 \%)$ dinyatakan tidak tuntas, dengan perolehan nilai rata-rata kelas sebesar 85,2.Sehingga secara klasikal hasil belajar mengajar pada akhir siklus II ini telah mencapai ketuntasan sebesar $\geq 85 \%$.Berikut grafik hasil siklus II.

Hasil Belajar Siklus II

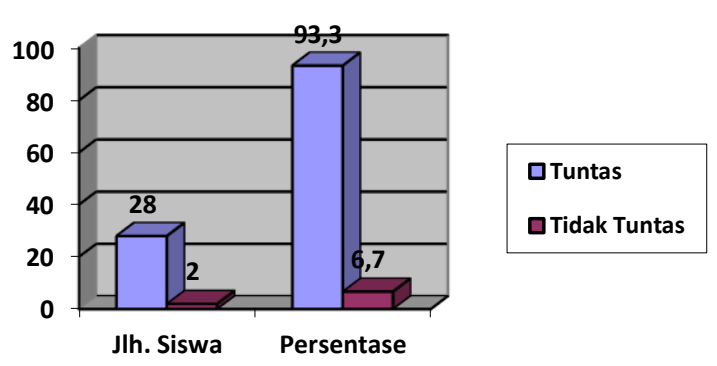

\section{KESIMPULAN}

Berdasarkan hasil penelitian dapat disimpulkan bahwa melalui penggunaan model pembelajaran problem base learning dapat meningkatkan pemahaman siswa pada materi pengertian dan fungsi busana pesta bagi siswa kelas XI Tata Busana-2SMK Negeri 1 Sigli, adalah hasil belajar pada siklus I dengan persentase ketuntasan sebesar $70 \%$ nilai rata-rata kelas sebesar 75,8 dan meningkat pada hasil tes siklus II sebesar $93,3 \%$ dengan nilai rata-rata kelas 85,2 . Pada kedua siklus ini terjadi perubahan aktifitas dan perolehan nilai yang signifikan bila dibandingkan dengan pra siklus dengan ketuntasan belajar yang hanya mencapai $46,7 \%$ dan nilai rata-rata adalah 66,2 .

\section{DAFTAR PUSTAKA}

Anies. 2003. Problem Based Learning. Artikel. Tersedia pada 
http://www.suara merdeka. com/harian/0304/28/kha2.htm. Diunduh tanggal 11 Januari 2016.

Anas Sudijono. 2005. Pengantar Evaluasi Pendidikan. Jakarta : PT. Raja Grafindo Persada.

Aqib, Zainal, 2009. Penelitian Tindakan Kelas untuk Guru. Bandung: YramaWidya

Hamalik, Oemar. 2008. Proses Belajar Mengajar. Jakarta: PT BumiAksara.

Sanjaya, Wina. 2008. Kurikulum Dan Pembelajaran. Jakarta: Kencana Prenada Media Group.

Slameto. 2003. Belajar dan faktor - faktor yang mempengaruhinya. Jakarta: Rineka cipta.

Sri Widarwati, 2000. Desain Busana I. Yogyakarta: IKIP Yogyakarta
Sri Widarwati, dkk. 2000. Desain Busana II. Yogyakarta: IKIP Yogyakarta.

Sudijono. 2005. Pengantar Evaluasi Pendidikan. Jakarta: PT. Raja Grafindo Persada.

Sudjana, Nana. 2009. Penilaian Hasil Proses Belajar Mengajar. Bandung: Remaja Rosda karya.

Sugiyanto. 2008. Model-model Pembelajaran Inovatif. Surakarta: Panitia Sertifikasi.

Sutrisno. 2006. Fisika dan Pembelajarannya. Bandung: UPI.

Taufiq Amir. 2009. Inovasi Pendidikan Melalui Problem Based Learning. Jakarta: Kencana Prenada Media Group. 